\title{
The Relationship of Indonesiaan Language Learning with the Environment
}

\author{
Pebi Kusuma Dewi/19016039 \\ pebikusumadewi0710@gmail.com
}

God will not create something without any benefit stored in it, as well as the environment. The environment is not only for humans. Stay, but more than that. The environment provides tremendous benefits for human life. In addition, the environmnet also has a positive impact on the process student learning. The environment can be used as an object that can be used teachers in the application of the Indonesian language learning process. When students feel fed up or bored in the monotonous process of learning Indonesian, then this environment-based learning can be used as another alternative.

So far, Indonesia language learning always makes students bored with language learning monotonous learning process. This is in accordance with the opinion of Bunga (in Ramadhan et al, 2016) than lack motivation from within students causes students to do not like writing activities. For students who have low learning motivation, activities writing becomes a boring, difficult, and less important activity to do. Learning is closely related to the environment of students. Slamet (n Ramadhan et al, 2013) said psychologically learning is a process of change in behavior as a result of interaction eith the environment in fulfilling necessities of life.

Through environmental-based Indonesian language learning, it is can make learning Indoneisa, especially writing skills better interesting in they eyes of students. An attractive learning model will make attitides and students motivation in learning will also increase. This can be done if in the learning process is not monotonous. Effort to improve learning attitudes are accompanied by a positive learning attitude to words the lesson, foe example growing an attitude of liking and love the Indonesian language lesson, always repeating the lesson an so on (Ramadhan et al, 2013). Apart from that, learning Indonesia too requires teaching materials that can attract students interest in following the lesson. According to Richard and Renandya (in Sukma et al, 2019), teaching materials will have a major impact on students the quality of learning in the classroom, because teaching materials are an effetive way to reflect learning.

The application of environmental-based Indonesia learning can included in the argumentation text. Ramadhan et al (2016) says students skill in writing argumentative essays about the environment will make students as intellectuals who are smart and care about the environment. Environmental education life is a conscious effort made to teach or interest people about how the natural environment functions and how humans can manage and protect it that. In order for students to participate in protecting the environment, it is important to develop knowledge of the environment, environmental awareness and behavior change to words environment. Individuals should be encouraged not to view the environment as something that should be exploited for their purposes, but as a valuable asset worth protecting for human survival (Sukma et al, 2019).

Not only argumentative text, but also experimental report text requires the environment as an object. This indicates that the environment and Indonesian language learning cannot be separated. This is in line with that Sukma et al (2015) stated that in the implementation of learning to write reports using a scientifict approach in elementary scholls has aspects of observing, asking, experimenting, reasoning, and networking. It can be implemented on 
environment, so that the environment becomes the main object in carrying out the experiment. Suyana and Manuaba (in Sukma et al, 2020) stated that the use of scientific knowledge is to improve students cognitive abilities, train students to improve higher order thinking skills, training to solve problems effectively structured, improve learning outcomes, create learning conditions in which students feel that learning is very important in life, it increases significantly for students, train students in communicating ideas and foster student character in the right direction more positive.

Environmentally based Indonesian learning has a purpose so that students know what problems exist in the environment. This can be realized if the teacher participates in it. Regarding this, teacher is the most important indicator in improving the learning process. According to Ramadhan et al (2019), the teacher is a very decisive component in implementation a strategy in streamlining the learning process. Successful implementation of a learning strategies depend on the teacher's expertise in using methods, techniques, and teaching tactics. This is in line with what was conveyed by Ramadhan et al (2020) if adequate environmental education systems are mapped out and aimed at provide awareness, conscience, and information about environmental issues to students from all levels.

Based on the questionnaire that the 1 author distributed regarding "Language Learning Relationships Indonesia with the Environment" to 10 Padang State University students, 6 Andalas University students, 3 Padang State Polytechic students, 1 student from Stikes Mercubakti Jaya Padang, 2 students from Poltekkes Ministry of Health Padang, 1 student of the Academy Prayoga Padang Pharmacy, 1 student at Taman Siswa Padang University, 1 person Riau University student, one Indonesian Pionerer University student, one person STKIP PGRI West Sumatra student, and 1 student of the West Sumatra Shipping Polytechic. The total number respondents who participate in filling out a questionnaire regarding the "Relation to Indonesian Langauge Learning with the Environment" as many as 30 people with a percentage of 13,2\% of respondents aged 18 years, 13,2\% of respondents aged 19 years, 45,5\% respondents aged 20 years, $19,8 \%$ of respondents aged 21 years, and 3,3 respondents aged 23 years.

The first statement "Environment-based Indonesian language learning as an effort build the ecological intelligence of students" $60 \%$ stated strongly agree, $40 \%$ agree, $0 \%$ disagree, and $0 \%$ disagree. Statement second "Learning Indonesian with the theme of the environment is one of the strategies to develop students' mindsets and patterns of action" $60 \%$ stated very agree, $40 \%$ agree, $0 \%$ disagree, and $0 \%$ disagree. The third statement "Utilizing learning themes about nature in various aspects need to be done for the enrichment of Indonesian language learning reading materials" $56.7 \%$ strongly agree, $40 \%$ agree, $3.3 \%$ disagree, and $0 \%$ disagree. The fourth statement "Environmental materials can be applied in Indonesian language learning through text content read or written by participants students" $53.3 \%$ stated strongly agree, $46.7 \%$ agreed, $0 \%$ stated less agree, and $0 \%$ disagree. Fifth statement "Indonesian language learning environmentbased can increase the creativity of students" 56.7\% stated very agree, $43.3 \%$ agree, $0 \%$ disagree, and $0 \%$ disagree agree. The sixth statement "With Indonesian-based learning environment can specifically improve linguistic intelligence (listening, speaking, reading and writing)" $70 \%$ strongly agree, $30 \%$ agree, $0 \%$ disagree, and $0 \%$ disagree. The seventh statement "Master has important contribution in introducing environmental knowledge through classroom learning" $63.3 \%$ strongly agree, $30 \%$ agree, $6.7 \%$ disagree, and $0 \%$ disagree. Eighth statement "Use of the environment is wrong an effective learning media to be applied in the learning 
process" $63.3 \%$ stated strongly agree, $36.7 \%$ agree, $0 \%$ disagree, and $0 \%$ say do not agree. The ninth statement "Environmental conservation efforts can be included in Indonesian reading texts for students" $56.7 \%$ stated strongly agree, $43.3 \%$ agree, $0 \%$ disagree, and $0 \%$ disagree. Statement the last "Environmental material can influence student achievement in learning Indonesian language" $43.3 \%$ stated strongly agree, $40 \%$ agreed, $16.7 \%$ stated disagree, and $0 \%$ disagree

In accordance with the results of the distribution of the questionnaire that has been carried out by the author, it can be concluded that learning Indonesian has a very close relationship with environment. This can be proven by the response of respondents to the statement that the author gave through the questionnaire, where most of the respondents gave a response that strongly agrees regarding learning Indonesian language which is related to environment. Based on this, the application of Indonesian language learning that environmentbased can be applied in the learning process. 


\section{Daftar Pustaka}

Ramadhan, S., Atmazaki, dan Zulhafizh. (2013). Kontribusi Sikap dan Motivasi Belajar Siswa terhadap Hasil Belajar Bahasa Indonesia. Jurnal Bahasa, Sastra, dan Pembelajaran, 1(2), 13-26.

Ramadhan, S., dan Diana Putri. (2019). Korelasi Keterampilan Membaca Pemahaman dan Keterampilan Menulis Teks Laporan Hasil Observasi Siswa Kelas VII SMP Negeri 4 Pariaman. Jurnal Pendidikan Bahasa dan Sastra Indonesia dan Daerah, 8(1), 62-69.

Ramadhan, S., Elfia Sukma, dan Vivi Indriyani. (2020). Integration of Enviromental Education in Elementary Schools. IOP Conference Series: Earth and Enviromental Science, 1481, p. 1-6.

Ramadhan, S., Ena Noveria, dan Tri Wasillah. (2016). Pengaruh Model Pembelajaran Kooperatif Tipe Think Pair Share terhadap Keterampilan Menulis Naskah Drama Satu Babak Siswa Kelas VII SMP Negeri 30 Padang. Jurnal Pendidikan Bahasa dan Sastra Indonesia dan Daerah, 5(1), 8-16.

Ramadhan, S., Harris Effendi Thahar, dan Hasian Ramadon Tanjung. (2013). Pengaruh Model Pembelajaran Kooperatif Tipe Think Pair Share dan Tipe Two Stay Stray terhadap Hasil Belajar Bahasa Indonesia Siswa Kelas X SMA Negeri 1 Angkola Barat Kabupaten Tapanuli Selatan. Jurnal Bahasa, Sastra, dan Pembelajaran, 1(1), 94-107.

Ramadhan, S., Nursaid, dan Ira Guci. (2016). Korelasi Penguasaan Kosakata Bidang Lingkungan Hidup dengan Menulis Karangan Argumentasi tentang Lingkungan Hidup. Jurnal Pendidikan Bahasa dan Sastra Indonesia,5(2), 169-174.

Sukma, E., dan Annisa Safitri. (2020). Peningkatan Hasil Belajar Siswa pada Tema 3 Menggunakan Pendekatan Saintifik di Sekolah Dasar. Jurnal Pendidikan Tambusai, 4(3), 3132-3144.

Sukma, E., Rizky Amelia, dan Nur Asma. (2015). Pembelajaran Menulis Laporan Percobaaan dengan Pendekatan Saintifik di Sekolah Dasar, Seminar Nasional Jurusan PGSD FIP $U N P$.

Sukma, E., Syahrul Ramadhan, dan Vivi Indriyani. (2019). Enviromental Education and Disaster Mitigation Through Language Learning. 314, p. 1-9.

Sukma, E., Syahrul Ramadhan, dan Vivi Indriyani. (2019). Persepsi Guru terhadap Penggunaan Bahan Ajar Bahasa Indonesia dengan Perangkat Seluler dan Aplikasi Edmodo, Seminar Internasional Riksa Bahasa. 